\title{
UJI EFEK EKSTRAK ETANOL DAUN CINCAU HIJAU (Cyclea barbata Miers) SEBAGAI ANTIINFLAMASI PADA TIKUS PUTIH YANG DIINDUKSI KARAGEN
}

\author{
Irma Santi, Bayu Putra, Sri Wahyuni \\ Fakultas Farmasi Universitas Muslim Indonesia, Makassar \\ Email: irma.santi@umi.ac.id
}

\begin{abstract}
Inflammatory medication which is commonly used is the treatment synthetically or traditionally from the natural ingredients, the green grass jelly leaves (Cyclea barbata Miers). This research aimed to determine the effects and the most effective dose of the ethanol extract of green grass jelly leaves as an antiinflammatory in white rats induced by carrageenan. This research used 15 mice divide into 5 group. Group I (negative control) was given Na.CMC; group II (positive control) was given Na.Diclofenac; group III, IV and $V$ were given ethanol extract of green grass jelly leaves (EEDCH) at the dose of $1.875 \mathrm{mg} / \mathrm{kgBW}, 3.75 \mathrm{mg} / \mathrm{kgBW}$, and $7.5 \mathrm{mg} / \mathrm{kgBW}$. Pretreatment on animals induced by carrageenan 1\% amounted to $0.1 \mathrm{~mL}$ in sub plantar on the soles of the mice. The measurements were made every 1 hour for 5 hour by using the pletismometer tool. The result showed that the ethanol extract of green grass jelly leaves has a potential as anti-inflammatory. Based on the result of statistical analysis of the one way ANOVA followed by Post Hoc Test LSD showed that substance EEDCH at the dose of $7.5 \mathrm{mg} / \mathrm{kgBW}$ has antiinflammatory effect were not significantly different from the positive control (Na.Diclofenac).
\end{abstract}

Keywords: Green grass jelly leaves (Cyclea barbata Miers), anti-inflammatory, Na.Diclofenac.

\section{PENDAHULUAN}

$$
\text { Inflamasi adalah respons }
$$

protektif setempat yang ditimbulkan oleh cedera atau kerusakan jaringan, yang berfungsi menghancurkan, mengurangi, atau mengurung suatu agen pencedera maupun jaringan yang cedera itu. ${ }^{1}$ Gejala respon inflamasi meliputi rubor (kemerahan), kalor (panas), dolor (nyeri), turgor (pembengkakan). ${ }^{2} \quad$ Inflamasi disebabkan oleh pelepasan mediator kimia dari jaringan yang rusak dan migrasi sel. ${ }^{3}$

Pengobatan yang selama ini dilakukan pada umumnya untuk memperlambat atau membatasi proses kerusakan jaringan yang terjadi 
Uji efek ekstrak etanol daun cincau hijau (yclea barbata Miers) sebagai antiinflamasi pada tikus putih yang diinduksi karagen

pada daerah inflamasi. Obat modern yang biasa digunakan ialah obat antiinflamasi nonsteroid (AINS) yang memiliki efek samping pada saluran cerna yaitu menyebabkan tukak lambung. ${ }^{4,5}$ Oleh karena itu pemanfaatan tumbuhan obat dengan khasiat antiinflamasi perlu dilakukan untuk menemukan alternatif pengobatan dengan efek samping yang relatif lebih kecil.

Salah satu tumbuhan di Indonesia yang sejak dahulu digunakan untuk pengobatan adalah cincau hijau (Cyclea barbata Miers.) dari Famili Menispermaceae. Kandungan kimia aktif yang terdapat dalam tumbuhan ini adalah klorofil, karbohidrat, alkaloid siklein, tetrandin, dimetil tetrandin, polifenol, saponin, dan flavonoid. ${ }^{6}$ Daun cincau hijau telah lama dijadikan bahan baku minuman cincau yang dipercaya berkhasiat untuk mengobati demam, sakit perut atau lambung, radang ${ }^{7}$, serta dapat menurunkan tekanan darah dan mengatasi panas dalam. ${ }^{6}$ Masyarakat di jawa barat juga telah lama menggunakan daun cincau hijau secara topikal untuk menyembuhkan demam. ${ }^{8}$

Daun Cyclea barbata Miers diketahui mengandung klorofil, serta senyawa bioaktif polifenol, saponin, flavonoid dan lemak. Keempat komponen ini secara umum dikenal sebagai antioksidan, antikanker, dan antiinflamasi. ${ }^{9}$ Flavanoid merupakan senyawa yang memiliki aktivitas farmakologi sebagai antiinflamasi. Peran flavanoid sebagai antiinflamasi adalah dengan menurunkan jumLah leukosit dan mengurangi aktivitas komplemen sehingga menurunkan adhesi leukosit ke endotel dan mengakibatkan penurunan respon inflamasi. ${ }^{10}$ Penelitian terdahulu Trimurtini (2007) diketahui bahwa ekstrak air daun cincau hijau dapat memperbaiki kerusakan mukosa gaster dan menurunkan kadar $\mathrm{HCl}$ gaster yang diinduksi aspirin. ${ }^{11}$

Oleh karena itu perlu dilakukan agar dapat mengetahui efek ekstrak etanol daun cincau hijau (Cyclea barbata Miers) sebagai antiinflamasi pada tikus putih yang diinduksi karagen. Sehingga penelitian ini mampu memberikan data ilmiah tentang pemanfaatan daun cincau hijau (Cyclea barbata Miers) sebagai antinflamasi.

\section{METODE KERJA}

Penelitian ini dilakukan secara eksperimental laboratorium dengan menggunakan Metode Pembentukan Edema Buatan. Untuk menimbulkan edema pada kiki tikus diinduksi 
Uji efek ekstrak etanol daun cincau hijau (yclea barbata Miers) sebagai antiinflamasi pada tikus putih yang diinduksi karagen

dengan karagen $\lambda 1 \%$ secara subplantar.

\section{Alat dan Bahan}

Alat-alat yang digunakan adalah Pletismometer, rotary evaporator, spoit, jarum oral, timbangan. Bahanbahan yang digunakan dalam penelitian ini antara lain, Ekstrak daun cincau hijau (Cyclea barbata Miers),etanol $70 \%, \mathrm{NaCl}$, aquadest, karagenan $\lambda 1 \%$, Natrium diklofenak, $\mathrm{Na}$ CMC.

\section{Prosedur Kerja}

\section{Pembuatan suspensi Na.CMC 1\%} b/v

Na.CMC ditimbang sebanyak 0,5 gram, dimasukkan sedikit demi sedikit ke dalam $50 \mathrm{~mL}$ air suling panas (suhu $70^{\circ} \mathrm{C}$ ) sambil diaduk dengan menggunakan pengaduk elektrik hingga terbentuk larutan koloidal yang homogen, kemudian dicukupkan volumenya hingga $100 \mathrm{~mL}$ dengan air suling.

Pembuatan suspensi karagen $\lambda 1 \%$ b/v

Karagen ditimbang sebanyak 0,1 gram, ditambah larutan $\mathrm{NaCl} 5 \mathrm{~mL}$, dihomogenkan kemudian dicukupkan volumenya hingga $10 \mathrm{~mL}$.

Pembuatan Natrium diklofenak 50 $\mathrm{mg} / \mathrm{kgBB}$

Natrium diklofenak ditimbang sebanyak 22,925 mg kemudian dimasukkan kedalam lumpang, ditambahkan larutan koloidal Na.CMC $1 \%$ sedikit demi sedikit sambil digerus hingga homogen lalu dimasukkan kedalam labu tentukur $10 \mathrm{~mL}$ dan volumenya dicukupkan sampai $10 \mathrm{~mL}$.

\section{Pembuatan ekstrak etanol daun cincau hijau}

Daun cincau hijau dikeringkan, dan diserbukkan menjadi $300 \mathrm{~g}$ serbuk, dimaserasi dengan etanol $70 \%$. Dilakukan remaserasi sebanyak 5 kali hingga memperoleh hasil ekstraksi yang jernih. Ekstrak yang diperoleh kumpulkan dan pekatkan dengan menggunakan rotavapor untuk menguapkan pelarut, menghasilkan ekstrak kental dan timbang.

Pembuatan sediaan uji suspensi ekstrak daun cincau hijau

Dibuat suspensi ekstrak daun cincau hijau dengan perbandingan dosis yaitu dosis $1,875 \mathrm{mg}$ dibuat sebanyak $1,875 \mathrm{mg}$ dalam $10 \mathrm{~mL}$ $\mathrm{Na} . \mathrm{CMC} 1 \% \mathrm{~b} / \mathrm{v}$, dosis $3,75 \mathrm{mg}$ dibuat sebanyak $3,75 \mathrm{mg}$ dalam $10 \mathrm{~mL}$ Na.CMC $1 \%$ b/v dan dosis $7,5 \mathrm{mg}$ sebanyak $7,5 \mathrm{mg}$ dalam $10 \mathrm{~mL}$ Na.CMC 1\% b/v.

\section{Pemilihan dan pemeliharaan Hewan} Uji

Hewan uji yang digunakan adalah tikus putih jantan galur wistar, sehat, umur 2-3 bulan, bobot 150-200 
Uji efek ekstrak etanol daun cincau hijau (yclea barbata Miers) sebagai antiinflamasi pada tikus putih yang diinduksi karagen

gram sebanyak 15 ekor, dimana hewan terlebih dahulu ditempatkan dalam kandang yang sesuai dengan kelompok perlakuan. Kemudian tikus diadaptasikan selama 1 minggu dan diberi makan dan minum.

\section{Perlakuan terhadap Hewan Uji}

Tikus diadaptasikan dalam kandang kurang lebih selama 1 minggu untuk proses aklimatisasi. Selama proses tersebut, dijaga agar kebutuhan makan dan minum tetap terpenuhi.

Dipuasakan tikus selama 8 jam sebelum perlakuan, namun air minum tetap diberikan. Kemudian ditimbang berat badannya. Semua hewan uji diukur terlebih dahulu volume kakinya (Volume awal) menggunakan plestimometer. Semua hewan uji diinduksi dengan karagen $\lambda 1 \% \mathrm{~b} / \mathrm{v}$ sebanyak $0,1 \mathrm{~mL}$ secara subplantar. Kemudian dilakukan pengukuran edema dengan menggunakan pletismometer

Hewan uji dibagi dalam 5 kelompok dengan jumLah 3 ekor pada masing-masing kelompok perlakuan. Kelompok I diberi Na.CMC sebagi kontrol negatif, kelompok II diberi suspensi natrium diklofenak sebagai kontrol positif, kelompok III diberi ekstrak etanol daun cincau hijau dengan dosis 1,875 $\mathrm{mg} / \mathrm{kgBB}$, kelompok IV diberi ekstrak etanol daun cincau hijau dengan dosis 3,75 $\mathrm{mg} / \mathrm{kgBB}$, kelompok $\mathrm{V}$ diberi ekstrak etanol daun cincau hijau dengan dosis $7,5 \mathrm{mg} / \mathrm{kgBB}$. Pemberian dilakukan melalui oral.

\section{Pengukuran Volume Edeama}

Pengukuran volume edema pada telapak kaki tikus dilakukan dengan cara mencelupkan kaki tikus ke dalam pletismometer setiap selang waktu 1 jam selama 5 jam. Kemudian dilihat volume radang berdasarkan kenaikan raksa pada pletismometer.

\section{HASIL PENELITIAN}

Hasil penelitian uji efek ekstrak etanol daun cincau hijau (Cyclea barbata Miers) dapat dilihat pada tabel 1 di bawah ini : 
Uji efek ekstrak etanol daun cincau hijau (Cyclea barbata Miers) sebagai antiinflamasi pada tikus putih yang diinduksi karagen

Tabel 1. Data hasil rata-rata pengukuran volume edema $(\mathrm{mL})$ setelah diinduksi karagen $1 \%$ dan setelah perlakuan.

\begin{tabular}{|c|c|c|c|c|c|c|c|}
\hline \multirow{2}{*}{$\begin{array}{l}\text { Kelompok } \\
\text { perlakuan }\end{array}$} & \multirow{2}{*}{$\begin{array}{c}\text { Sebelum } \\
\text { induksi } \\
\text { karagen } \\
\pm S D\end{array}$} & \multirow{2}{*}{$\begin{array}{c}\text { Setelah } \\
\text { induksi } \\
\text { karagen } \\
\pm \text { SD }\end{array}$} & \multicolumn{5}{|c|}{ Volume edema $(\mathrm{mL}) \pm \mathrm{SD}$} \\
\hline & & & Jam 1 & Jam 2 & Jam 3 & Jam 4 & Jam 5 \\
\hline Na.CMC & $\begin{array}{c}1,90 \pm \\
0,04\end{array}$ & $\begin{array}{c}3,15 \pm \\
0,02\end{array}$ & $\begin{array}{c}3,23 \pm \\
0,03\end{array}$ & $\begin{array}{c}3,34 \pm \\
0,03\end{array}$ & $\begin{array}{c}3,50 \pm \\
0,03\end{array}$ & $\begin{array}{c}3,56 \pm \\
0,04\end{array}$ & $\begin{array}{c}3,60 \pm \\
0,03\end{array}$ \\
\hline Na.DIK & $\begin{array}{c}1,93 \pm \\
0,01\end{array}$ & $\begin{array}{c}3,57 \pm \\
0,05\end{array}$ & $\begin{array}{c}3,17 \pm \\
0,17\end{array}$ & $\begin{array}{c}2,92 \pm \\
0,23\end{array}$ & $\begin{array}{c}2,68 \pm \\
0,35\end{array}$ & $\begin{array}{c}2,33 \pm \\
0,05\end{array}$ & $\begin{array}{c}2,20 \pm \\
0,06\end{array}$ \\
\hline $\begin{array}{c}\text { EEDCH } 1,875 \\
\mathrm{mg} / \mathrm{kgBB}\end{array}$ & $\begin{array}{c}1,90 \pm \\
0,01\end{array}$ & $\begin{array}{c}3,16 \pm \\
0,05\end{array}$ & $\begin{array}{c}2,95 \pm \\
0,06\end{array}$ & $\begin{array}{c}2,69 \pm \\
0,13\end{array}$ & $\begin{array}{c}2,52 \pm \\
0,03\end{array}$ & $\begin{array}{c}2,35 \pm \\
0,08\end{array}$ & $\begin{array}{c}2,20 \pm \\
0,03\end{array}$ \\
\hline $\begin{array}{c}\text { EEDCH 3,75 } \\
\mathrm{mg} / \mathrm{kgBB}\end{array}$ & $\begin{array}{c}1,85 \pm \\
0,06\end{array}$ & $\begin{array}{c}3,19 \pm \\
0,08\end{array}$ & $\begin{array}{c}3,01 \pm \\
0,06\end{array}$ & $\begin{array}{c}2,71 \pm \\
0,07\end{array}$ & $\begin{array}{c}2,51 \pm \\
0,09\end{array}$ & $\begin{array}{c}2,30 \pm \\
0,04\end{array}$ & $\begin{array}{c}2,16 \pm \\
0,08\end{array}$ \\
\hline $\begin{array}{c}\text { EEDCH 7,5 } \\
\mathrm{mg} / \mathrm{kgBB}\end{array}$ & $\begin{array}{c}1,91 \pm \\
0,04 \\
\end{array}$ & $\begin{array}{c}3,32 \pm \\
0,07\end{array}$ & $\begin{array}{c}3,06 \pm \\
0,10 \\
\end{array}$ & $\begin{array}{c}2,82 \pm \\
0,07 \\
\end{array}$ & $\begin{array}{c}2,54 \pm \\
0,16 \\
\end{array}$ & $\begin{array}{c}2,27 \pm \\
0,07 \\
\end{array}$ & $\begin{array}{c}2,10 \pm \\
0,06 \\
\end{array}$ \\
\hline
\end{tabular}

Tabel 2. Data persentase penurunan volume edema

\begin{tabular}{lc}
\hline \multicolumn{1}{c}{ Kelompok Perlakuan } & $\%$ Penurunan \\
\hline Kelompok I (Na.CMC) & $-14,27 \%$ \\
Kelompok II (Na.DIK) & $38,43 \%$ \\
Kelompok III (EEDCH 1,875 mg/kgBB) & $30,34 \%$ \\
Kelompok IV (EEDCH 3,75 mg/kgBB) & $32,09 \%$ \\
Kelompok V (EEDCH 7,5 mg/kgBB) & $36,75 \%$ \\
\hline
\end{tabular}

\section{PEMBAHASAN}

Inflamasi adalah respon

perlindungan tubuh terhadap cedera atau kerusakan jaringan yang disebabkan oleh mikroorganisme, trauma fisik, dan bahan kimia berbahaya. $^{12}$

Penelitian ini bertujuan untuk menentukan efek ekstrak etanol daun cincau hijau (Cyclea barbata Miers) sebagai antiinflamasi dan untuk menentukan dosis efektif ekstrak etanol daun cincau hijau (Cyclea barbata Miers) sebagai antiinflamasi pada tikus putih yang diinduksi karagen.

Pada penelitian ini digunakan sampel yaitu ektrak etanol daun cincau hijau (Cyclea barbata Miers) dan hewan uji yang digunakan adalah tikus jantan yang dibagi dalam 5 kelompok dengan jumLah 3 ekor pada masingmasing kelompok perlakuan. Semua hewan uji diinduksi dengan karagen $1 \% \mathrm{~b} / \mathrm{v}$ sebanyak $0,1 \mathrm{~mL}$ secara subplantar. Setelah 1 jam kemudian, kelompok I diberi Na.CMC sebagi kontrol negatif, kelompok II diberi 
Uji efek ekstrak etanol daun cincau hijau (yclea barbata Miers) sebagai antiinflamasi pada tikus putih yang diinduksi karagen

suspensi natrium diklofenak sebagai kontrol positif, kelompok III diberi ekstrak etanol daun cincau hijau dengan dosis $1,875 \mathrm{mg} / \mathrm{kgBB}$, kelompok IV diberi ekstrak etanol daun cincau hijau dengan dosis 3,75 $\mathrm{mg} / \mathrm{kgBB}$, kelompok $\mathrm{V}$ diberi ekstrak etanol daun cincau hijau dengan dosis $7,5 \mathrm{mg} / \mathrm{kgBB}$. Pemberian dilakukan melalui oral. Kemudian dilakukan pengukuran edema dengan menggunakan pletismometer dan pengukuran penurunan volume edema kaki tikus dilakuakan setiap 1 jam selama 5 jam.

Sampel daun cincau hijau (Cyclea barbata Miers) diketahui mengandung klorofil, serta senyawa bioaktif polifenol, saponin, flavonoid dan lemak. Keempat komponen ini secara umum dikenal sebagai antioksidan, antikanker, dan antiinflamasi. ${ }^{9}$ Flavanoid merupakan senyawa yang memiliki aktivitas farmakologi sebagai antiinflamasi. Peran flavanoid sebagai antiinflamasi adalah dengan menurunkan jumLah leukosit dan mengurangi aktivitas komplemen sehingga menurunkan adhesi leukosit ke endotel dan mengakibatkan penurunan respon inflamasi. ${ }^{10}$

Pengujian efek antiinflamasi dilakukan berdasarkan parameter penurunan volume edema telapak kaki tikus yang diinduksi karagen $1 \%$ secara subplantar. Karagen sebagai senyawa iritan menginduksi terjadinya cedera sel melalui pelepasan prostaglandin yang mengawali proses inflamasi. Pengujian inflamasi dengan menggunakan karagen merupakan pengujian yang sederhana, mudah dilakukan dan sering dipakai. Karagen digunakan sebagai penginduksi karena mudah diterima oleh fisiologis tubuh sehingga respon inflamasi cepat terjadi dan pembengkakannya lebih nyata sehingga mudah untuk diamati. Keuntungan lain dari penggunaan karagen adalah tidak menimbulkan kerusakan jaringan, dan tidak menimbulkan bekas. ${ }^{13}$

Pada penelitian antiinflamasi digunakan pembanding untuk melihat perbandingan antara obat dan ekstrak yang digunakan. Kontrol positif yang digunakan sebagai pembanding pada penelitian ini adalah natrium diklofenak. Natrium diklofenak merupakan obat antiinflamasi non steroid yang termasuk kedalam kelompok preverencially selective COX inhibitor. Obat ini bekerja menghambat aktivitas enzim siklooksigenase yang berperan dalam metabolisme asam arakidonat menjadi prostaglandin yang merupakan salah 
Uji efek ekstrak etanol daun cincau hijau (yclea barbata Miers) sebagai antiinflamasi pada tikus putih yang diinduksi karagen

satu mediator inflamasi. ${ }^{14}$ Obat ini umum digunakan sebagai kontrol positif dalam penelitian antiinflamasi. Obat ini memiliki daya antiradang yang paling kuat dengan efek samping yang lebih kecil dibandingkan dengan obat lainnya (indometasin, piroksikam). ${ }^{15}$

Pengujian ini dilakukan dengan menggunakan alat pletismometer yang prinsip kerjanya berdasarkan hukum Archimedes yaitu benda yang dimasukkan kedalam zat cair akan memberikan gaya atau tekanan keatas sebesar volume yang dicelupkan. ${ }^{16}$

Data hasil pengukuran volume edema ekstrak daun cincau hijau (Cyclea barbata Miers) dapat dilihat pada tabel dan gambar 1 . Selanjutnya data hasil pengukuran dari tabel 1 kemudian dibuat persentase penurunan yang dapat dilihat pada tabel 2, yang menunjukkan pada kelompok kontrol positif (Na.Diklofenak) mengalami penurunan yang paling besar yaitu 38,43\%, setelah itu kelompok $V$ (EEDCH 7,5 $\mathrm{mg} / \mathrm{kgBB}$ ) yang mengalami penurunan dengan jumLah persentase $36,75 \%$, kemudian kelompok IV (EEDCH 3,75 $\mathrm{mg} / \mathrm{kgBB}$ ) yaitu $32,09 \%$ dan yang paling kecil kelompok III (EEDCH $1,875 \mathrm{mg} / \mathrm{kgBB}$ ) yaitu $30,09 \%$. Tetapi pada kelompok kontrol negatif
(Na.CMC) tidak mengalami penurunan yaitu $-14,27 \%$,

Analisis data hasil penelitian penurunan volume edema diolah secara statistik menggunakan One Way ANOVA menunjukkan hasil yang berbeda nyata secara signifikan antar kelompok perlakuan $(p=0,001)$ Karena hasil yang diperoleh signifikan, maka dilanjutkan pada Post Hoc Test dengan uji LSD untuk melihat perbedaan antar kelompok.

Dari hasil analisis diperoleh bahwa kelompok kontrol negatif (Na.CMC) berbeda nyata dengan semua kelompok perlakuan $(p=0,001)$. Hal ini menunjukkan bahwa Na.CMC tidak memiliki efek sebagai antiinflamasi. Sedangkan pada kelompok kontrol positif (Na.Diklofenak) tidak berbeda nyata dengan bahan uji EEDCH dosis 7,5 $\mathrm{mg} / \mathrm{kgBB} \quad(p \geq 0,883)$, tetapi berbeda nyata dengan dosis $1,875 \mathrm{mg} / \mathrm{kgBB}$ $(p=0,001)$ dan dosis $3,75 \mathrm{mg} / \mathrm{kgBB}$ $(p=0,001)$. Berdasarkan hasil tersebut dapat dikatakan bahwa efek antiinflamasi bahan uji EEDCH dosis $7,5 \mathrm{mg} / \mathrm{kgBB}$ setara dengan kontrol positif (Na.Diklofenak), tetapi tidak pada dosis $1,875 \mathrm{mg} / \mathrm{kgBB}$ dan dosis $3,75 \mathrm{mg} / \mathrm{kgBB}$ yang menunjukkan pebedaan nyata dengan kontrol positif (Na.Diklofenak). 
Uji efek ekstrak etanol daun cincau hijau (yclea barbata Miers) sebagai antiinflamasi pada tikus putih yang diinduksi karagen

\section{KESIMPULAN}

Ekstrak etanol daun cincau hijau (Cyclea barbata Miers) memiliki efek sebagai antiinflamasi. Ekstrak etanol daun cincau hijau (Cyclea barbata Miers) yang paling efektif ialah pada konsentrasi $7,5 \mathrm{mg} / \mathrm{kgBB}$ dengan persen penurunan $36,75 \%$.

\section{DAFTAR PUSTAKA}

1. Sudoyo AW. Buku Ajar IImu Penyakit Dalam. Edisi 4 Jilid 2. Pusat Penerbitan IImu Penyakit Dalam FKUI: Jakarta, 2007.

2. Corwin EJ. Handbok of Pathophysiology $3^{\text {th }}$ edition. Lippincort Williams \& Wilkins: Philadelphia, 2008.

3. Mycek MJ, Haevery RA and Champe PC. Farmakologi Ulasan Bergambar. Edisi II. diterjemahkan dari Bahasa inggris oleh Agoes A. Penerbit Widya Medika: Jakarta, 2001.

4. Tjay TH, Rahardja K. Obat-obat Penting : Khasiat, Penggunaan, dan Efek-Efek Sampingnya. Edisi VI. PT. Elex Media Komputindo, Jakarta, 2007.

5. Wilmana PF. Farmakologi dan Terapi Bagian Farmakologi Fakultas Kedokteran Universitas Indonesia: Jakarta, 1995.

6. Angelina $M$, Hartati $S$, Dewijanti LD, Banjarnahor SDS, Meilawati L. Penetuan LD50 Daun Cinco (Cyclea Barbata MIERS) pada mencit. Makaro Sains 2008; 12(1):23-26.
7. Chalid SY. Pengaruh Ekstrak Cincau Hijau (Cyclea barbata Miers) terhadap Aktivitas Enzim Superoksida Dismutase dan Katalase pada Mencit $\mathrm{C} 3 \mathrm{H}$ Bertumor Kelenjar Susu (Tesis). Program Pascasarjana Institut Pertanian Bogor: Bogor, 2003.

8. Roosita K, Kusharto CM, Sekiyama M, Fachrurozi Y, Ohtsuka R. Medical Plants Used by The Villagers of a Sundanese Community in West Java. Journal of Ethnopharmacology 2008.

9. Heny $\mathrm{AH}$, Dian $\mathrm{H}$. Potensi cincau hijau (Cyclea barbata L. Miers) sebagai pangan fungsional. Balai Pengkajian Teknologi Pertanian: Jawa Barat, 2004.

10. Nijveldt RJ, Nood EV, Hoorn DECV, Boelens PG, Norren KV, Leeuwen PAMV. Flavonoids: a review of probable mechanisme of action and potential applications. American Journal of Clinical and Nutrition 2001.

11.Trimurtini I. Pengaruh ekstrak air daun cincau hijau (Cyclea barbata Myer's) pada mukosa dan kadar $\mathrm{HCl}$ gaster tikus galur wistar yang diinduksi aspirin Disampaikan pada PIN PAAI: Padang, 2007.

12. Harvey RA, Champe PE. Farmakologi Ulasan Bergambar. EGC: Jakarta, 2014.

13. Yuslinda E, Hasti S, Wati E. Efek Antiinflamasi fraksi Heksan Dan Fraksi Etil Asetat Daun Alpikat (Persea americana Mill.). Pada Tikus (Rattus norvergicus) Putih Jantan. J.Sains Tek Far 2011.

14. Kertia N. Aktivitas Antiinflamasi Kurkuminoid Ekstrak Rimpang Kunyit. Program Doktor IImu 
Uji efek ekstrak etanol daun cincau hijau (yclea barbata Miers) sebagai antiinflamasi pada tikus putih yang diinduksi karagen

Kedokteran dan Kesehatan. Fakultas Kedokteran Universitas Gadjah Mada: Yogyakarta, 2009.

15. Tjay TH. Rahardja K. Obat obat Penting: Khasiat, Penggunaan dan Efek-Efek Sampingnya Edisi $V$.
Penerbit PT. Elex Media Komputindo: Jakarta, 2002.

16. Hidayati AN., Kandungan Kimia dan Uji Antiinflamasi Ekstrak Etanol Lantana camara L. Pada Tikus Putih (Rattus norvegicus) Jantan. Bioteknologi 2005; 5(1): 11-13. 